\title{
Severe hypernatraemia in adults
}

\author{
PETER DAGGETT, JOHN DEANFIELD, FIONA MOSS, DAVID REYNOLDS
}

British Medical fournal, 1979, 1, 1177-1180

\section{Summary and conclusions}

In a prospective study of abnormalities of plasma sodium concentration carried out over one year 20 patients were identified who had a concentration exceeding $154 \mathrm{mmol}(\mathrm{mEq}) / \mathrm{l}$. Of these, eight patients had diabetes mellitus, eight had primary intracranial disorder, and four had become dehydrated. Five of the eight diabetics presented with hyperosmolar, non-ketotic precoma, and in all eight hypernatraemia developed despite treatment with hypotonic $(0 \cdot 45 \%)$ saline. There was a good correlation $(r=-0.93)$ between the rates of change of plasma sodium and blood glucose concentrations, and thus a rise in plasma sodium concentration appeared to be a consequence of the treatment. In the early phase of treatment urinary sodium loss was extremely low despite a brisk diuresis, the infused sodium then predisposing the patients to hypernatraemia. All of the eight patients with intracranial disorders showed evidence of abnormal production of the antidiuretic hormone, six having frank diabetes insipidus. Severe hypernatraemia in this group was associated with a high mortality, fluid balance being difficult to maintain. Two of the four patients who had become dehydrated had had a recent gastrointestinal haemorrhage. In these patients infusion of $0.9 \%$ saline contributed to the hypernatraemia since urinary sodium loss was low.

Severe hypernatraemia in adults is uncommon, but in established cases plasma and urinary biochemical indices should be measured frequently. Monitoring of the central venous pressure is usually necessary, and patients are best managed in an intensive care unit.

\section{Introduction}

Plasma sodium concentrations are frequently measured in clinical practice, but major perturbations are uncommon. In view of the complexity of the factors controlling sodium homoeostasis, ${ }^{1}$ it would be surprising if the plasma sodium concentration were kept within a narrow range as constantly as everyday experience suggests. Reports based on systematic review of laboratory results ${ }^{2}$ have indicated that hyponatraemia is not rare, a view supported by our own findings (to be published). Hypernatraemia, on the other hand, appears to be genuinely uncommon, although it has been a problem in paediatric practice. ${ }^{4}$ It is important to be aware that this abnormality may occur in adults, since "at-risk" groups may be defined. We report here our findings based on a review of every estimation of plasma sodium concentration carried out in the clinical chemistry laboratory over one year.

\footnotetext{
The Central Middlesex Hospital, London NW10

PETER DAGGETT, MRCP, senior registrar (present address: Middlesex Hospital, London W1)

JOHN DEANFIELD, MRCP, registrar

FIONA MOSS, MRCP, senior house officer, department of medicine and endocrinology (present address: Brompton Hospital, London SW3)

DAVID REYNOLDS, MRCPATH, senior registrar, department of clinical chemistry (present address: Hammersmith Hospital, London W12)
}

\section{Patients and methods}

Plasma sodium concentrations were measured by atomic emission spectrophotometry, using a Technicon SMA plus AutoAnalyzer, reading the $589 \mathrm{~nm}$ sodium peak. The reference range $(95 \%$ confidence limits) based on a hospital outpatient population is $131-143 \mathrm{mmol}$ (mEq)/l for this method. Plasma osmolality was measured by the depression of freezing point method, using an Advanced Instruments osmometer. For the purposes of our survey we defined severe hyponatraemia and hypernatraemia as being values outside the range 121$154 \mathrm{mmol} / \mathrm{l}$ (about $5 \mathrm{SD}$ from the population mean). Abnormal results by these criteria were notified to one of us; the patients were then visited, with the permission of their clinicians. Arrangements were made to carry out additional investigations and record the patients' progress. When a patient had hypernatraemia the following investigations were carried out. Plasma sodium, potassium, urea, glucose, bicarbonate, and creatinine concentrations and osmolality were measured daily. Fluid balance was recorded and urinary electrolytes and osmolality measured. When possible we obtained a value for the venous packed cell volume, but since in many of the patients haematological indices were measured out of office hours, these data are incomplete.

\section{Results}

Between 1 November 1977 and 31 October 197820 patients were identified in whom the plasma sodium concentration exceeded $154 \mathrm{mmol} / \mathrm{l}$ on at least two occasions. Eight of these patients had diabetes mellitus, eight had primary intracranial disorder, while the remaining four had no common factor other than dehydration.

\section{PATIENTS WITH DIABETES MELLITUS}

Of the eight patients with diabetes mellitus, two (cases 5 and 8 table I) were in ketoacidotic precoma on admission, one (case 1) had sustained a thrombotic hemiplegia at a time when her diabetes was stable, but the other five fulfilled the criteria for hyperosmolar, nonketotic diabetic coma. The patient in case 1 had mild diabetes, normally controlled by diet. Dexamethasone ( $20 \mathrm{mg}$ daily) was given because of her neurological lesion and an infusion of $0.9 \%$ saline kept running for access to the circulation. After initial improvement her condition worsened again and she was found to be hyperosmolar, although her blood glucose concentration was lower than that usually found in this syndrome. Her records showed that she had received $1137 \mathrm{mmol}$ of sodium over eight days, during which she had sustained a fluid deficit of 2.51 .

The patients in cases 5 and 8 received conventional treatment for ketoacidosis, consisting of infusion of $0.9 \%$ saline, with insulin by pump at the rate of 6 units/h. When the plasma sodium concentration began to rise the infused fluid was changed to $0.45 \%$ saline, the insulin dosage remaining the same. The patients with hyperosmolar, nonketotic diabetes were treated with $0.45 \%$ saline throughout, apart from an initial infusion of $0.9 \%(500 \mathrm{ml})$ set up in the accident and emergency department. The fluid was given in these patients under the control of measurements of central venous pressure, most receiving 31 within the first six hours of treatment. Insulin was given by pump, as for ketoacidosis, at the rate of 6 units/h. The plasma sodium concentrations rose in every patient (for cases 2-8: $t=9.17, \mathrm{P}<0.001$ ) and blood glucose concentrations fell $(t=2 \cdot 89, \mathrm{P}<0.02)$, but there was no significant change in the plasma osmolality (table I). During this time the patients' fluid balance was strongly positive and a mean of $365 \mathrm{mmol}$ of sodium was given, compared with a mean urinary sodium loss of only $18.7 \mathrm{mmol}$. There was a close correlation between the rate of change of plasma sodium and blood glucose concentrations (fig $1 ; \mathrm{r}=-0.93, \mathrm{P}<0.01$ ).

Subsequent management of hypernatraemia-All eight patients were treated similarly, the following protocol being started when the peak concentrations shown in table I were reached. The infusion fluid was changed to $5 \%$ dextrose, which was given at the rate of 11 every four hours, provided this did not cause the central venous pressure to 


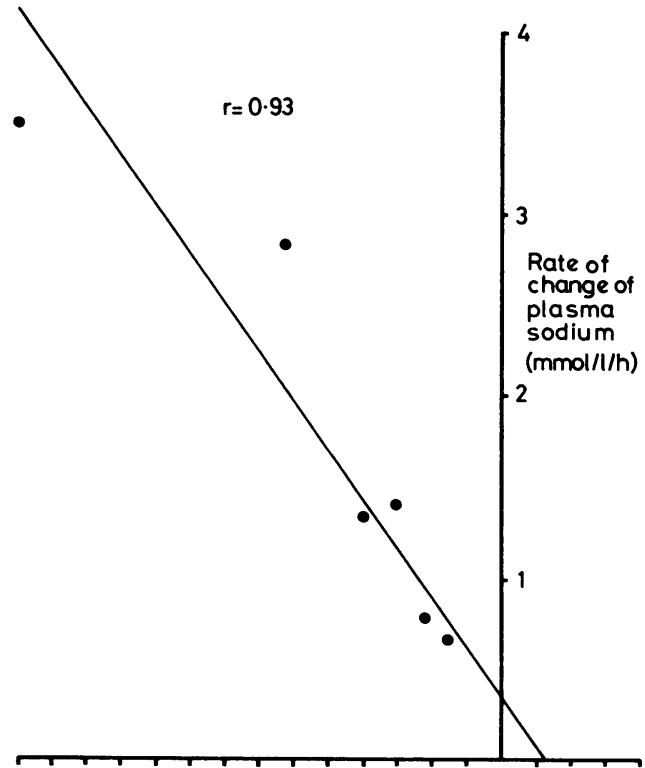

$\begin{array}{lllllllllllllllllll}4 & 13 & 12 & 11 & 10 & 9 & 8 & 7 & 6 & 5 & 4 & 3 & 2 & 1 & 0 & 1 & 2 & 3 & 4\end{array}$ Rate of change of blood glucose $(\mathrm{mmol} / / \mathrm{h})$

FIG 1-Rate of change of plasma sodium concentration compared with rate of change of blood glucose concentration.

Conversion: SI to traditional units-Plasma sodium: $1 \mathrm{mmol} / 1=1 \mathrm{mEq} / 1$. Blood glucose: $1 \mathrm{mmol} / 1 \approx 18 \mathrm{mg}$ $100 \mathrm{ml}$.

exceed $8 \mathrm{~cm}$. Insulin was continued by pump, at an initial rate of 6 units/h, adjusted on the basis of two-hourly measurements of the blood glucose concentration. This regimen halted the rise in the plasma sodium concentration, and only one patient (who had had a stroke) died. The mean time taken for the plasma sodium concentration to return to normal, however, was 26 hours after the start of the regimen.

\section{PATIENTS WITH INTRACRANIAL DISORDERS}

Five of the eight patients in this group were hypernatraemic on admission, two (cases 9 and 12, see table II) dying within six hours of their neurological illness. In the six who survived for more than six hours the hypernatraemia worsened or developed for the first time while they were under observation. The fluid balance of these patients was inaccurate because they were often confused or incontinent, and evidence of diabetes insipidus was therefore sought by simultaneously measuring plasma and urinary osmolalities. Diabetes insipidus was clearly present in cases $10,12,13,14$, and 15 and almost certainly in case 11 , in which the urine osmolality of $342 \mathrm{mmol}(\mathrm{mosmol}) / \mathrm{kg}$ was lower than that expected for a plasma value of $340 \mathrm{mmol} / \mathrm{kg}$ (table II).
The diagnosis was supported in these six cases by an observed urine output exceeding $150 \mathrm{ml} / \mathrm{h}$ for two consecutive hours, and subsequently by the therapeutic response to desmopressin. The patients in cases 9 and 16 were not polyuric but were clinically dehydrated. The urine was only moderately concentrated in the presence of pronounced plasma hyperosmolality, and after rehydration in case 16 the urine volume increased and its osmolality fell. Thus these patients probably had partial diabetes insipidus, which therefore contributed to the

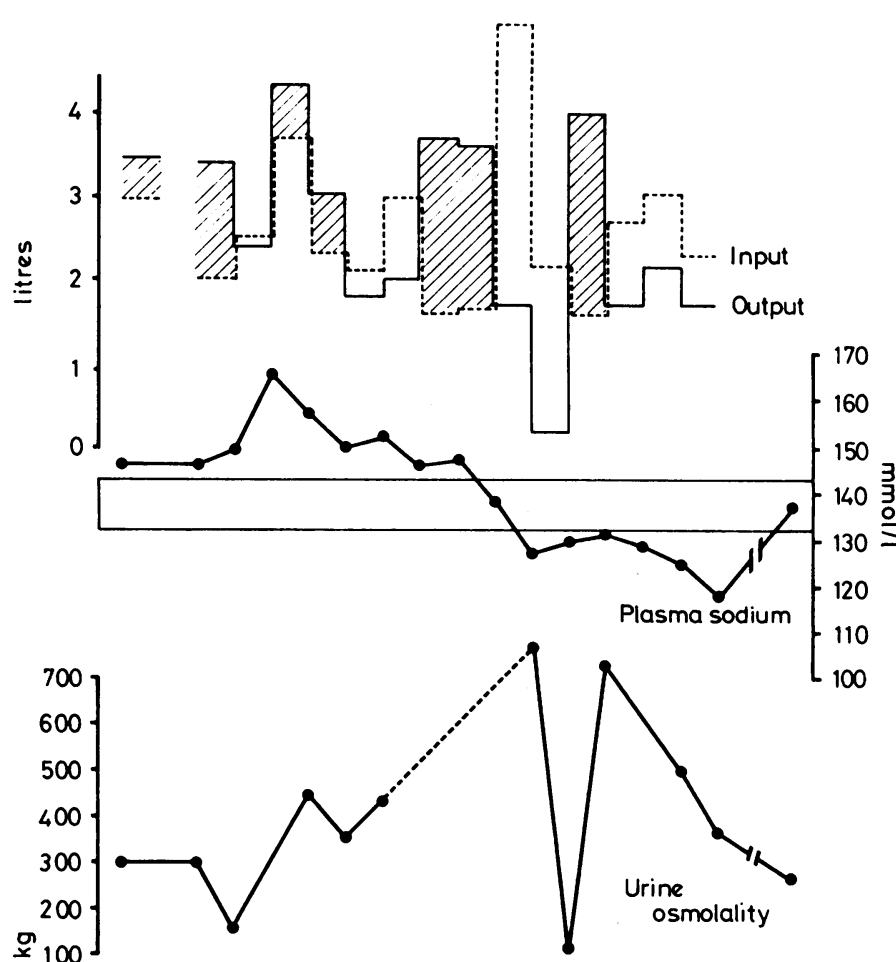

ڤั)

Desmopressin $2 \mu g$

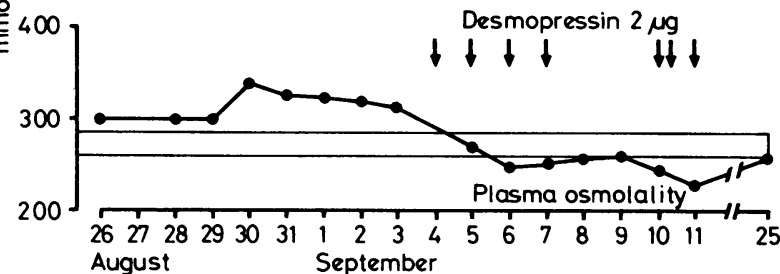

pIG 2-Case 14. Plasma and urinary osmolalities and plasma sodium concentration during treatment. Bar graph shows fluid balance, with hatched areas indicating negative balance. Horizontal lines indicate reference ranges.

Conversion: SI to traditional units-Plasma sodium: $1 \mathrm{mmol} / 1=1 \mathrm{mEg} / \mathrm{l}$ Osmolality: $1 \mathrm{mmol} / \mathrm{kg}=1 \mathrm{mosmol} / \mathrm{kg}$.

TABLE I-Biochemical indices in patients with hypernatraemia and diabetes mellitus

\begin{tabular}{|c|c|c|c|c|c|c|c|c|c|c|c|c|}
\hline \multirow{3}{*}{$\begin{array}{l}\text { Case } \\
\text { No }\end{array}$} & \multicolumn{3}{|c|}{ At admission } & \multicolumn{3}{|c|}{ At peak sodium concentration } & \multirow{3}{*}{$\begin{array}{l}\text { Time between } \\
\text { admission and } \\
\text { peak sodium } \\
\text { concentration }\end{array}$} & \multirow{2}{*}{\multicolumn{2}{|c|}{$\begin{array}{l}\text { Rate of change of } \\
\text { concentration } \\
(\mathrm{mmol} / \mathrm{h})\end{array}$}} & \multicolumn{3}{|c|}{$\begin{array}{l}\text { Balance between admission and } \\
\text { peak sodium concentration }\end{array}$} \\
\hline & \multirow{2}{*}{$\begin{array}{l}\text { Plasma } \\
\text { sodium } \\
(\mathrm{mmol} / \mathrm{l})\end{array}$} & \multirow{2}{*}{$\begin{array}{c}\text { Plasma } \\
\text { glucose } \\
(\mathrm{mmol} / \mathrm{l})\end{array}$} & \multirow{2}{*}{$\begin{array}{c}\text { Plasma } \\
\text { osmolality } \\
(\mathrm{mmol} / \mathrm{kg})\end{array}$} & \multirow{2}{*}{$\begin{array}{c}\text { Plasma } \\
\text { sodium } \\
(\mathrm{mmol} / \mathrm{l})\end{array}$} & \multirow{2}{*}{$\begin{array}{l}\text { Plasma } \\
\text { glucose } \\
(\mathrm{mmol} / \mathrm{l})\end{array}$} & \multirow{2}{*}{$\begin{array}{c}\text { Plasma } \\
\text { osmolality } \\
(\mathrm{mmol} / \mathrm{kg})\end{array}$} & & & & & Plasma & Plasma \\
\hline & & & & & & & & $\begin{array}{l}\text { Plasma } \\
\text { sodium }\end{array}$ & $\begin{array}{l}\text { Plasma } \\
\text { glucose }\end{array}$ & $\underset{(\mathrm{ml})}{\text { Fluid }}$ & $\begin{array}{l}\text { sodium } \\
\text { (mput } \\
\text { (mmol)* }\end{array}$ & $\begin{array}{c}\text { sodium } \\
\text { output } \\
\text { (mmol)† }\end{array}$ \\
\hline $\begin{array}{l}17 \\
2 \\
3 \\
4 \\
5 \\
6 \\
7 \\
8\end{array}$ & $\begin{array}{l}138 \\
141 \\
144 \\
145 \\
142 \\
150 \\
146 \\
142\end{array}$ & $\begin{array}{l}18 \cdot 5 \\
43 \cdot 0 \\
61 \cdot 4 \\
57.3 \\
118 \\
57.5 \\
49 \cdot 2 \\
57 \cdot 1\end{array}$ & $\begin{array}{l}309 \\
365 \\
403 \\
377 \\
421 \\
397 \\
365 \\
386\end{array}$ & $\begin{array}{l}165 \\
155 \\
160 \\
162 \\
163 \\
162 \\
158 \\
156\end{array}$ & $\begin{array}{l}35 \cdot 2 \\
12 \cdot 5 \\
36 \cdot 6 \\
20 \cdot 1 \\
34 \cdot 0 \\
21 \cdot 7 \\
19 \cdot 8 \\
16 \cdot 9\end{array}$ & $\begin{array}{l}382 \\
357 \\
393 \\
364 \\
378 \\
371 \\
352 \\
359\end{array}$ & $\begin{array}{r}8 \text { days } \\
10 \text { hours } \\
28 \text { hours } \\
6 \text { hours } \\
6 \text { hours } \\
9 \text { hours } \\
18 \text { hours } \\
18 \text { hours }\end{array}$ & $\begin{array}{l}1.4 \\
0.57 \\
2.83 \\
3.5 \\
1.33 \\
0.67 \\
0.78\end{array}$ & $\begin{array}{l}3 \cdot 1 \\
0 \cdot 89 \\
6 \cdot 2 \\
14 \\
4 \\
1 \cdot 63 \\
2 \cdot 23\end{array}$ & $\begin{array}{l}-2500 \\
+2800 \\
\mathrm{NA} \\
+1400 \\
+2800 \\
+3400 \\
+3100 \\
+1800\end{array}$ & $\begin{array}{l}1137 \\
323 \\
\text { NA } \\
300 \\
450 \\
495 \\
345 \\
270\end{array}$ & $\begin{array}{c}\text { NA } \\
11 \\
\text { NA } \\
6 \\
30 \\
21 \\
12 \\
32\end{array}$ \\
\hline Mean \pm SD $\ddagger$ & $144 \pm 3 \cdot 1$ & $63 \cdot 4 \pm 24$ & $9388 \pm 20 \cdot 7$ & $159 \pm 3 \cdot 2$ & $23 \cdot 1 \pm 8 \cdot 9$ & $368 \pm 14 \cdot 2$ & 13.6 hours & $1 \cdot 58$ & $4 \cdot 58$ & +2550 & 365 & $18 \cdot 7$ \\
\hline
\end{tabular}

*Input of sodium as intravenous saline (mainly $0.45 \%$ ). 
TABLE II-Details of patients with hypernatraemia and intracranial disorders

\begin{tabular}{|c|c|c|c|c|c|c|c|c|c|c|}
\hline \multirow[b]{2}{*}{$\begin{array}{l}\text { Case } \\
\text { No }\end{array}$} & \multicolumn{3}{|c|}{ At admission } & \multicolumn{3}{|c|}{ At peak sodium concentration } & \multirow{2}{*}{$\begin{array}{l}\text { Urinary osmolality } \\
\text { at peak sodium } \\
\text { concentration } \\
(\mathrm{mmol} / \mathrm{kg})\end{array}$} & \multirow{2}{*}{$\begin{array}{l}\text { Mechanism of } \\
\text { raised sodium } \\
\text { concentration }\end{array}$} & \multirow[b]{2}{*}{ Primary disorder } & \multirow[b]{2}{*}{ Outcome } \\
\hline & $\begin{array}{l}\text { Plasma } \\
\text { sodium } \\
(\mathrm{mmol} / \mathrm{l})\end{array}$ & $\begin{array}{c}\text { Plasma } \\
\text { osmolality } \\
(\mathrm{mmol} / \mathrm{kg})\end{array}$ & $\begin{array}{c}\text { Packed } \\
\text { cell } \\
\text { volume }(\%)\end{array}$ & $\begin{array}{l}\text { Plasma } \\
\text { sodium } \\
(\mathrm{mmol} / \mathrm{l})\end{array}$ & $\begin{array}{l}\text { Plasma } \\
\text { osmolality } \\
(\mathbf{m m o l} / \mathbf{k g}) \text { vo }\end{array}$ & $\begin{array}{l}\text { Packed } \\
\text { cell } \\
\text { olume }(\%)\end{array}$ & & & & \\
\hline 9 & 162 & 363 & $34 \cdot 9$ & \multicolumn{3}{|c|}{ On admission } & 660 & \multirow{2}{*}{$\begin{array}{c}\text { Dehydration } \\
\text { ?partial DI } \\
\text { DI }\end{array}$} & Severe head injury & \multirow{2}{*}{$\begin{array}{l}\text { Died } \\
\text { Died }\end{array}$} \\
\hline 10 & 146 & 309 & NA & 158 & 342 & NA & 120 & & \multirow{2}{*}{$\begin{array}{l}\text { Severe head injury, } \\
\text { hyperpyrexia } \\
\text { Craniopharyngioma } \\
\text { Thrombotic } \\
\text { cerebrovascular } \\
\text { accident* }\end{array}$} & \\
\hline $\begin{array}{l}11 \\
12\end{array}$ & $\begin{array}{l}142 \\
158\end{array}$ & $\begin{array}{l}300 \\
328\end{array}$ & $\begin{array}{l}38.0 \\
\text { NA }\end{array}$ & 163 & On admission & $28 \cdot 0$ & $\begin{array}{l}342 \\
164\end{array}$ & $\begin{array}{l}\text { DI } \\
\text { DI }\end{array}$ & & $\begin{array}{l}\text { Survived; well } \\
\text { Died }\end{array}$ \\
\hline 13 & 134 & 284 & $46 \cdot 2$ & 166 & 354 & $48 \cdot 2$ & 105 & DI & Recurrent & Died \\
\hline 14 & 146 & 308 & $38 \cdot 6$ & 166 & 348 & NA & 155 & DI & Hypothalamic glioma & \multirow{2}{*}{$\begin{array}{l}\text { Survived; obtunded but } \\
\text { improved by surgery } \\
\text { Survived; well } \\
\text { Died (of septicaemia) }\end{array}$} \\
\hline $\begin{array}{l}15 \\
16\end{array}$ & $\begin{array}{l}127 \\
158\end{array}$ & $\begin{array}{l}266 \\
341\end{array}$ & $\begin{array}{l}\text { NA } \\
\text { NA }\end{array}$ & $\begin{array}{l}155 \\
171\end{array}$ & $\begin{array}{l}322 \\
367\end{array}$ & $\begin{array}{l}46 \cdot 0 \\
\text { NA }\end{array}$ & $\begin{array}{l}200 \\
700\end{array}$ & $\underset{\substack{\text { Dehydration } \\
\text { ?partial DI }}}{\stackrel{\text { DI }}{\text { Deal }}}$ & $\begin{array}{l}\text { Severe head injury } \\
\text { Pituitary apoplexy } 2^{\circ} \\
\text { to acromegaly }\end{array}$ & \\
\hline
\end{tabular}

DI = Diabetes insipidus

NA $=$ Not available.

ral infarction.

Conversion: SI to traditional units-Plasma sodium: $1 \mathrm{mmol} / \mathrm{l}=1 \mathrm{mEq} / 1$. Osmolality: $1 \mathrm{mmol} / \mathrm{kg}=1 \mathrm{mosmol} / \mathrm{kg}$.

TABLE III-Details of the four patients with no common factor

\begin{tabular}{|c|c|c|c|c|c|c|c|c|c|c|}
\hline \multirow[b]{2}{*}{$\begin{array}{l}\text { Case } \\
\text { No }\end{array}$} & \multirow[b]{2}{*}{$\underset{\text { (years) }}{\text { Age }}$} & \multirow[b]{2}{*}{ Primary diagnosis } & \multicolumn{3}{|c|}{ At admission } & \multicolumn{3}{|c|}{ At peak sodium concentration } & \multirow{2}{*}{$\begin{array}{l}\text { Cumulative } \\
24-\text { hour fluid } \\
\text { balance (ml)* }\end{array}$} & \multirow{2}{*}{$\begin{array}{l}\text { 24-hour urinary } \\
\text { sodium output } \\
\text { (mmol)* }\end{array}$} \\
\hline & & & $\begin{array}{l}\text { Plasma } \\
\text { sodium } \\
(\mathbf{m m o l} / \mathbf{l})\end{array}$ & $\begin{array}{c}\text { Plasma } \\
\text { osmolality } \\
(\mathrm{mmol} / \mathrm{kg})\end{array}$ & $\begin{array}{c}\text { Packed } \\
\text { cell } \\
\text { volume (\%) }\end{array}$ & $\begin{array}{c}\text { Plasma } \\
\text { sodium } \\
(\mathrm{mmol} / \mathrm{l})\end{array}$ & $\begin{array}{c}\text { Plasma } \\
\text { osmolality } \\
(\mathrm{mmol} / \mathbf{k g})\end{array}$ & $\begin{array}{c}\text { Packed } \\
\text { cell } \\
\text { volume }(\%)\end{array}$ & & \\
\hline $\begin{array}{l}17 \\
18 \\
19 \\
20\end{array}$ & $\begin{array}{l}90 \\
72 \\
51 \\
48\end{array}$ & $\begin{array}{l}\text { Senile dementia } \\
\text { Parkinson's disease } \\
\text { Benign gastric ulcer } \\
\text { Duodenal ulcer }\end{array}$ & $\begin{array}{l}\text { NA } \\
141 \\
141 \\
137\end{array}$ & $\begin{array}{l}\text { NA } \\
297 \\
309 \\
317\end{array}$ & $\begin{array}{l}\text { NA } \\
40.5 \\
27.1 \\
48.5\end{array}$ & $\begin{array}{l}161 \\
155 \\
156 \\
159\end{array}$ & $\begin{array}{l}363 \\
358 \\
337 \\
351\end{array}$ & $\begin{array}{l}35 \\
48 \\
40 \\
28 \cdot 2\end{array}$ & $\begin{array}{l}-1950 \\
-2150 \\
-1150 \\
-1550\end{array}$ & $\begin{array}{l}\text { NA } \\
\text { NA } \\
25 \\
19\end{array}$ \\
\hline
\end{tabular}

* Values in 24 hours before peak sodium concentration.

Conversion: SI to traditional units-Plasma sodium: $1 \mathrm{mmol} / 1=1 \mathrm{mEq} / 1$. Plasma osmolality: $1 \mathrm{mmol} / \mathrm{kg}=1 \mathrm{mosmol} / \mathrm{kg}$.

severe hypernatraemia in every patient in this group. In cases in which data were available there was a poor correlation between the venous packed cell volume and either plasma sodium concentration or osmolality.

Subsequent management of hypernatraemia-Wide variations may occur in plasma and urinary biochemical indices over short periods (fig 2). Thus rigid protocols are seldom successful and we used the following treatment in these patients. An infusion of 5\% dextrose was run at the rate of one litre over two to four hours and repeated if necessary in order to relieve the clinical features of dehydration or to raise the central venous pressure to $0 \mathrm{~cm}$. If the urine flow before or after this exceeded $150 \mathrm{ml} / \mathrm{h}$ for two consecutive hours an intramuscular injection of $1 \mu \mathrm{g}$ of desmopressin was given, and repeated as necessary. If this was not effective the dose was increased to 2 to $4 \mathrm{\mu g}$. When the circulating volume was restored and the urine flow reduced the $5 \%$ dextrose infusion was adjusted to bring the plasma osmolality (measured four-hourly) to $300 \mathrm{mmol} / \mathrm{kg}$. The mortality in this group was high, the outcome being largely determined by the nature of the intracranial disease.

\section{PATIENTS WITH NO COMMON FACTOR}

In cases 17 and 18 the hypernatraemia was directly caused by dehydration and the peak values were recorded immediately before death (table III). The patients in cases 19 and 20 were admitted after having had large haematemeses and required urgent surgery. Their plasma sodium concentrations rose in the postoperative period, during the transfusion of packed cells. In both cases the fluid balance became negative while the urinary sodium loss was low. Both patients survived and were well on discharge. There was no correlation between the packed cell volume and plasma sodium concentration or osmolality when multiple samples from each patient were examined.

\section{Discussion}

Severe hypernatraemia, as defined by our criteria, is uncommon and occurred in only 20 out of 16224 admissions ( $0 \cdot 12 \%$ ) during a one-year period. It causes water to move from cells into the interstitial space, ${ }^{5}$ and when this occurs in the brain confusion, convulsions, and exacerbations of pre-existing cerebral disease may occur. ${ }^{6}$ The syndrome of hypernatraemic dehydration was common in children ${ }^{7}$ until it was recognised that strong salt or glucose ${ }^{8}$ solutions were dangerous. Apparently, similar factors may operate in adults, and the syndrome has occurred after the use of hypertonic dialysing solutions ${ }^{\circ}$ and topical hypertonic antiseptics. ${ }^{10}$ In addition, drugs such as phenytoin and steroids ${ }^{11}$ have been implicated, and in our study a patient developed a hyperosmolar state when given dexamethasone.

Hyperosmolar, non-ketotic diabetes ${ }^{12}$ is associated with hypernatraemia in at least $50 \%$ of cases, ${ }^{13}$ the $100 \%$ incidence in our series resulting from the method of selection. The mechanism of development of this syndrome was reviewed by Jaffe et al,,$^{14}$ but the reason for the hypernatraemia remains conjectural. In our cases the plasma sodium concentration rose after rapid rehydration, during which, despite using $0.45 \%$ saline, a large sodium load had been given. Little sodium was lost in the urine, so that the effect of sodium loading was accentuated. Our data suggest that with current treatment schedules a rise in plasma sodium concentration is inevitable. The intercept of the regression line in fig 1 shows that for a zero rate of change of plasma sodium concentration there must be a positive rate of changethat is, a rise- of the blood glucose concentration. Accordingly, an alternative to $0.45 \%$ saline and conventional insulin treatment is required. An infusion of $0.18 \%$ saline would cause haemolysis ${ }^{15}$ and predispose to the development of cerebral oedema. ${ }^{16}$ A safer fluid would be $2.5 \%$ dextrose (139 mmol $/ \mathrm{kg}$ ), but instead of changing the type of infusion fluid the rate of insulin infusion might be altered, both approaches being intended to lower the rate of change of the blood glucose concentration. The low mortality in this series was associated with a high standard of intensive care, and we recommend that patients with this condition are nursed in an intensive care unit.

Hypernatraemia in patients whose disease is primarily intracranial is usually caused by diabetes insipidus, there being little 
evidence for the existence of a separate entity of "essential hypernatraemia." 17 In some patients (such as the patient in case 16), however, the condition is masked by dehydration and declares itself only after fluid replacement. The wide variations in fluid requirement and output may be caused by fluctuations in the production of the antidiuretic hormone as a consequence of hypothalamic dysfunction. Because of this we recommend that measurements of plasma and urine osmolality and biochemical indices should be made at least twice daily during the acute phase of the illness. The hypernatraemia that occurred in the two patients in the group with no common factor who had undergone abdominal surgery was probably multifactorial in origin. Dehydration was prominent, but in addition sodium loading with low urinary loss, as occurred in the diabetic patients, played a part. Fluids with high sodium concentrations should, therefore, be used with care when surgery has been carried out for gastrointestinal haemorrhage.

Severe hypernatraemia in adults is uncommon, but patients who are likely to develop it may be identified easily. In established cases frequent measurements of plasma and urine biochemical indices and osmolality are required. Monitoring of central venous pressure is nearly always needed, and patients are best managed in an intensive care unit.

We are grateful to our colleagues who allowed us to study patients under their care and who obtained many additional diagnostic samples; and to the staff of the clinical chemistry laboratory for their help with the analyses and their splendid co-operation. We also pay tribute to the staff of the intensive therapy unit, who contributed in a major way to the successful treatment of many of the patients described in this paper.

\section{References}

1 Swales, J D, Sodium Metabolism in Disease. London, Lloyd-Luke, 1975.

2 Thomas, J H, et al, Lancet, 1978, 1, 621.

${ }^{3}$ Kennedy, P G E, Mitchell, D M, and Hoffbrand, B I, British Medical fournal, 1978, 2, 1251.

${ }^{4}$ Bannister, A, Martin-Siddiqy, S A, and Hatcher, G W, Archives of Disease in Childhood, 1975, 50, 179.

${ }^{5}$ Feig, P U, and McCurdy, M G, New England fournal of Medicine, 1977, 297, 1444.

6 Park, B E, Meacham, W F, and Netsky, M G, fournal of Neurosurgery, 1976, 44, 409.

7 Gammon, H R, Postgraduate Medical fournal, 1975, 51, suppl No 3, p 31.

8 Ware, S, Lancet, 1976, 1, 494.

' Boyer, J, Gill, G N, and Epstein, F H, Annals of Internal Medicine, 1967, $67,568$.

${ }^{10}$ Scoggin, C, McClellan, J R, and Cory, J M, Lancet, 1977, 1, 959.

${ }^{11}$ Brenner, W I, et al, Annals of Surgery, 1973, 178, 651.

12 Sament, S, and Schwartz, M B, South African Medical fournal, 1957, 31, 893.

13 Vaisrub, S, fournal of the American Medical Association, 1974, 227, 317.

${ }^{14}$ Jaffe, B, et al, Lancet, 1975, 1, 1069.

15 Blackwell, S W, and Burn-Cox, C J, Postgraduate Medical fournal, 1973, 49, 656.

${ }^{16}$ Clements, R S, Prockop, L D, and Winegrad, A I, Lancet, 1968, 2, 384.

${ }_{17}$ Sridhar, C B, Calvert, G D, and Ibbertson, H K, fournal of Clinical Endocrinology and Metabolism, 1974, 38, 890.

(Accepted 13 March 1979)

\title{
Fibromuscular dysplasia of the renal arteries
}

\author{
MATTIAS AURELL
}

British Medical fournal, 1979, 1, 1180-1181

\section{Summary and conclusions}

Two cases of severe fibromuscular dysplasia of the renal arteries are described in which the diagnosis was made 12 and 11 years after renal angiography had shown the arteries to be normal. The discovery of hypertension preceded the diagnosis by two and 11 years respectively, and in one case hypertension was present at the time of the normal renal angiogram.

The report suggests that fibromuscular dysplasia of the renal arteries is acquired and may not be present from birth. The importance of regular review in cases of severe hypertension is emphasised.

\section{Introduction}

Fibromuscular dysplasia of the renal arteries was first described in the late $1950 \mathrm{~s}^{12}$ Since then several hundred cases have been

\footnotetext{
Department of Medicine, Section of Nephrology, Sahlgrenska Hospital, University of Gothenburg, S-413 45 Gothenburg, Sweden MATTIAS AURELL, MD, associate professor of nephrology
}

reported, mostly from America. ${ }^{3-6}$ The changes in the renal arteries are a common cause of renovascular hypertension, but other vessels, including the splanchnic and the carotid arteries, may also be affected. In a personal, consecutive series of almost 200 cases of renovascular disease $15 \%$ of patients had fibromuscular dysplasia.

The aetiology of the disease is unknown. Women are more often affected than men (female to male ratio 4:1), multiparous women being particularly at risk. Nevertheless, cases have been described in infants and elderly people. Men with the disease often give a history of severe back trauma. No definite conclusions have been drawn about the natural history of the disease, but it has been suggested that it may be present from birth. I therefore report two cases in which renal angiograms were normal 12 and 11 years before severe fibromuscular dysplasia of the renal arteries was diagnosed. So far as I know this is the first such report.

\section{Case 1}

A 38-year-old woman with a family history of hypertension (a brother had died of uraemia due to hypertensive nephropathy) had been investigated at 19 and 23 years of age because of haematuria. No renal abnormality was detected (fig 1), and she was finally diagnosed as having a haemophilic disorder. Over the next 10 years she had four normal pregnancies. The last two deliveries, however, were complicated by placenta praevia and large blood losses, necessitating caesarean section. Raised blood pressure was noted during the fourth pregnancy, and two years later she was reinvestigated. 